( П. О. Киричок, д-р тех. наук, професор, О. О. Палюх, канд. техн. наук, доцент, КПІ ім. Ігоря Сікорського, Київ, Україна

\title{
КОНСТРУКТИВНІ ОСОБЛИВОСТІ ПОБУДОВИ ПРИСТРОЇВ І ШТАМПІВ ДЛЯ ВИГОТОВЛЕННЯ РОЗГОРТОК ПІВЖОРСТКИХ КНИЖКОВО-ЖУРНАЛЬНИХ ОБКЛАДИНОК
}

\begin{abstract}
Враховуючи відмінність висікання розгорток для паковань і обкладинок для книжкової продукції, яка полягає в тому, що книжкові блоки одного формату можуть мати корінцеву частину за розмірами відмінну одне видання від іншого, через зміну кількості сторінок, а, відповідно, і товщини корінцевої частини книжкового блоку, при збереженні всіх інших розмірів розгорток сталими, проведене дослідження відмінностей сприяло створенню багатофункціональної роз'ємної висікальної форми у якої, одна частина залишається нерухомою, а інша здійснює дискретні переміщення на визначену ширину, що відповідає ширині корінця книги, для якої висікається розгортка обкладинки.
\end{abstract}

Ключові слова: півжорстка обкладинка; крайки; клапани; розгортка; штанц-форма; висікальний пристрій; матриця; пуансон.

\section{Постановка проблеми}

Завданням дослідження конструктивних особливостей побудови пристроїв і штампів для виготовлення розгорток півжорстких книжково-журнальних обкладинок $€$ структурний аналіз механізмів, що забезпечують ефективне висікання складних конфігурацій розгорток із крайками і клапанами, які утворюють подвійну товщину обкладинок, а також можливість створення висікальної штанц-форми із рухомими висікальними елементами, яка забезпечить виготовлення розгорток півжорстких обкладинок для книжкових блоків однакового формату видання зі змінними розмірами корінцевої частини, пропорційними зміні товщини корінця книжкового блоку.

\section{Аналіз попередніх}

\section{досліджень}

Відомо, що серед різноманітних типів книжкових оправ окремою групою представлені півжорсткі обкладинки, що виготовлюються із одного аркуша палітурного матеріалу: картону, хром-ерзацу, щільного крейдованого паперу тощо [1].

У результаті висікання розгорток для таких обкладинок утворюються додаткові просторові конструкції у вигляді крайок і клапанів, що при загинанні всере-

\section{(C) $2019 p$.}


дину заготовки утворюють подвійну товщину обкладинки без проклеювання, або з проклеюванням [2].

Подвійна товщина обкладинки, залежно від конструкції і розмірів крайок та клапанів, можлива по всій внутрішній поверхні обкладинки, лише у зоні першої і другої сторінок обкладинки без заповнення зони відстави, або частковому заповненню зони відстави.

Висікання розгорток для півжорстких обкладинок, інтегральних обкладинок і заготовок покривного матеріалу для палітурок можливе на пресувально-висікальних пристроях для виготовлення розгорток паковань і тари із хром-ерзацу, мікро-гофрованого картону і картону товщиною до 1,2 мм.

Відомий пристрій (Патент US № 4643062, МПК В26F1/42), в якому виготовлення розгорток з картону відбувається шляхом пропускання встановленої на рухомих стрічках транспортера штанцювальної форми, з картонною заготовкою, між циліндрами, що обертаються. В результаті відбувається послідовне висікання розгортки шляхом взаємодії інструментів форми з опорною поверхнею циліндра.

Пристрій для виготовлення розгорток складної конфігурації по периметру (Патент № 57601 України, МПК В26 F1/38, B31B1) передбачає виготовлення розгорток з рухомої картонної стрічки і складається з матриці, виконаної у вигляді верхнього тигля та укомплектованої кривошипно-шатунним механізмом для забезпечення його вертикального переміщення, пуансона, виконаного у ви- гляді нижнього тигля та розміщеного на роликах, кулачкового механізму для забезпечення горизонтального переміщення вузла штанцювання, а також амортизатора для зрівноважування сил інерції мас тиглів.

В пристрої (Патент № 63710 України, МПК В26F 1/38, В31В $1 / 14$ д для виготовлення розгорток з картону міститься станина, вузол висікання у вигляді матриці та пуансона; матрицею є висікальна форма, встановлена нерухомо на станині, а пуансоном $є$ опорний циліндр, який розташовано на каретці, укомплектованій зубчастим вінцем для горизонтального переміщення каретки по нерухомій зубчастій рейці, яка закріплена на станині; пристрій додатково укомплектовано засобом дискретного переміщення картонної стрічки під час вистою циліндра у крайніх положеннях.

Пристрій (Патент № 76359 України МПК В31В 1/14, В26F 1/38) включає у структуру механізму комплекти ножів 3 ріжучими крайками, закріпленими під кутом до площини картону і протиножі, які виготовлені у формі циліндра і є рухомими; рухомі ножі з ріжучими крайками укомплектовані роликами, які контактують з пазовими кулачками, що забезпечують неперервність створення тиску у зоні вирізування розгортки; пристрій додатково укомплектовано засобами подачі картонної стрічки, виведення стрічки з вирізаними розгортками та поперечного розрізування стрічки на окремі розгортки.

\section{Мета роботи}

Враховуючи відмінність висікання розгорток для паковань i 
обкладинок, яка полягає у тому, що розгортки для паковання мають незмінні геометричні розміри зовнішнього контуру, визначені макетом, а обкладинки для книжкової продукції одного формату можуть мати корінцеву частину за розмірами відмінну одного видання від іншого, через зміну кількості сторінок, а, відповідно, і товщини корінцевої частини книжкового блоку, при збереженні всіх інших розмірів розгорток сталими, дослідженню підлягає можливість створення однієї висікальної штанц-форми для визначеного формату книжкових видань зі змінною товщиною корінцевої частини, а також конструктивні особливості висікально-пресувальних пристроїв, що здатні забезпечити висікання розгорток півжорстких обкладинок із змінними розмірами корінцевої частини.

\section{Результати проведених досліджень}

Відомо, що для виготовлення розгорток інтегральних обкладинок, обкладинок з клапанами різних просторових конструкцій, півжорстких обкладинок, заготовок покривного матеріалу палітурок, використовуються палітурні матеріали в перелік яких, в першу чергу, входять щільні сорти паперів, хром-ерзац різної товщини, окремі види картону тощо [3].

Механізми, за допомогою яких висікаються перелічені розгортки, за способом подачі палітурного матеріалу поділяються на два основні види, до складу яких входять пристрої, що подають окремі цільні аркуші палітурних матеріалів, або розмоту- ють стрічкові палітурні матеріали із рулонів у відповідних спеціалізованих пристроях.

Додатково, окрім висікання контуру розгортки обкладинок, необхідно нанести на розгортку лінії згинів, які виконуються бігувальними металевими лінійками одночасно із процесом висікання, або у іншій послідовності, передбаченій технологічним процесом, - до висікання контуру розгортки, після висікання, або після склеювання просторової конструкції, наприклад, півжорстких обкладинок.

Перелічені операції виконуються на спеціальних пресувальновисікальних пристроях за допомогою штанц-форм різної конфігурації [4], що для виготовлення серійних і дрібносерійних розгорток півжорстких обкладинок використовуються два основні види: плоскі та круглі і які, кожний вид, є основною складовою серії висікальних форм із особливостями побудови, визначеними конфігураціями книжковожурнальних оправ різних типів.

у загальному випадку, як правило, плоска висікальна форма, що має різальні та бігувальні металеві лінійки, закріплюється на верхній або нижній плиті спеціалізованого висікального преса. Палітурний матеріал майбутньої розгортки фіксується на допоміжній, також плоскій плиті. Процес висікання відбувається під час плоско-паралельного зближення плит до моменту проникнення різальних лінійок у матеріал і відсікання утвореної розгортки від залишків матеріалу та утворення облою [5].

Серед найбільш відомих і застосовуваних висікальних пресів 
виділяється серія пресів тигельного типу, у яких висікання розгорток із утворенням бігувальних ліній для майбутніх згинів здійснюється одночасно по всій площині, утвореній контуром заготовки для книжково-журнальної оправи (рис. 1).

Основними позитивними характеристиками тигельних висікальних пресів $€$ можливість використання в них однопозиційних штанц-форм і палітурних матеріалів форматами, які знаходяться в розмірному діапазоні А5-АЗ, що економічно доцільно при виготовленні оправ до малотиражної книжкової продукції, або подарункових видань кишенькового типу [6].

Основними особливостями пресів тигельного типу, що обмежують застосування широкого спектру палітурних матеріалів і можливостей підвищення продуктивності праці є:

- використання лише аркушевого матеріалу максимальним форматом A3;

- технологічний цикл висікання починається лише після введення заготовки палітурного матеріалу у зону плоско-паралельного зведення робочої та допоміжної плит;

- процес висікання потребує фіксації заготовки, утримування заготовки на термін технологічного процесу, унеможливлює швидку заміну утвореної розгортки, виведення облою і подачу наступного аркуша матеріалу;

- коливальний зворотно-поступальний рух тигельної плити викликає динамічні навантаження на механізм, що уповільнює процес холостого ходу до початку наступного циклу висікання розгортки;
- через реверсивний рух механізмів у пресах тигельного типу підтримується низька продуктивність технологічного процесу.

Частина недоліків, притаманних пресам тигельного типу, в обмеженні розмірів висікального штампу, а, відповідно, і формату отримуваної розгортки, відсутня у стоп-циліндрових пристроїв висікання розгорток для книжково-журнальних оправ, які сприяють висіканню розгорток за допомогою багатопозиційних штанцформ із палітурних матеріалів A1, або А0 форматів без обмеження номенклатури матеріалів [7].

Кількісна позиційність штанцформи для таких пристроїв визначається форматами видань i, відповідно, розмірами розгорток для книжково-журнальних оправ.

Конструкція стоп-циліндрового пристрою для висікання розгортки (рис. 2) складається із металевого циліндра 2 із затиска-

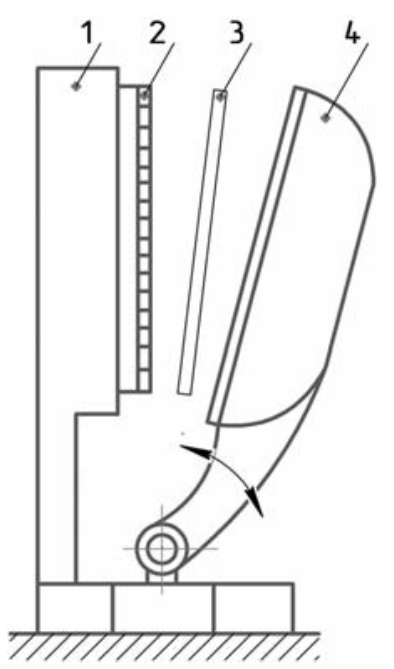

Рис. 1. Графічна схема тигельного висікального пресу: 1 - нерухома станина; 2 - висікальна форма; 3 - заготовка палітурного матеріалу; 4 - коливальний тигель 
чами 3, які транспортують аркуш палітурного матеріалу 1 у зону послідовного висікання під час контакту циліндру 2, що обертається, із штанц-формою 5, яка рухається назустріч циліндру із матеріалом заготовки.

Штанц-форма закріплена на рухомому талері 6 , який котиться в сторону циліндра, під час робочого циклу, і від нього, під час холостого ходу, на роликах транспортуючого рольгангу 7, розташованого на нерухомій станині 8. Під час холостого ходу, при поверненні талера у початкове положення, циліндр, із затискачами 3 для палітурних матеріалів, піднімається догори за допомогою куліси 4 і зупиняється, очікуючи завершення холостого ходу талера.

До наступної групи висікальних пресів належать пристрої, що забезпечують високу продуктивність технологічного процесу за рахунок висікання розгорток із стрічкових палітурних матеріалів, що розмотуються з рулонів різної ширини.

Висікання відбувається у процесі циклічних зупинок, лише для зведення висікальних плит механізму та отримання розгортки необхідної конфігурації, яка переміщається у наступному циклі із зони висікання у зону виведення іï із стрічки матеріалу i складуванні на палету, як завершеного півфабрикату. Момент виведення висіченої розгортки із стрічки матеріалу співпадає 3 наступним циклом висікання наступної розгортки.

На рис. 3 представлено удосконалений авторами пристрій для висікання розгорток книжково-журнальних обкладинок, який включає механізм висікання у вигляді поворотного шарнірного чотириланковика, до складу якого входять плоскі рухомі плити, закріплені на кривошипах [8].

Шарнірні чотириланковики здійснюють обертово-паралельний рух симетрично матеріалу заготовки. Висікальна форма закріплена на верхній плоскій плиті, а стрічкопротягувальний механізм укомплектований ввідними з радіусами $\mathrm{R}_{1}$ і вивідними з радіусами $\mathrm{R}_{3}$ (рис. 3) парами валиків, в кожній із яких валики обертаються назустріч один одному.

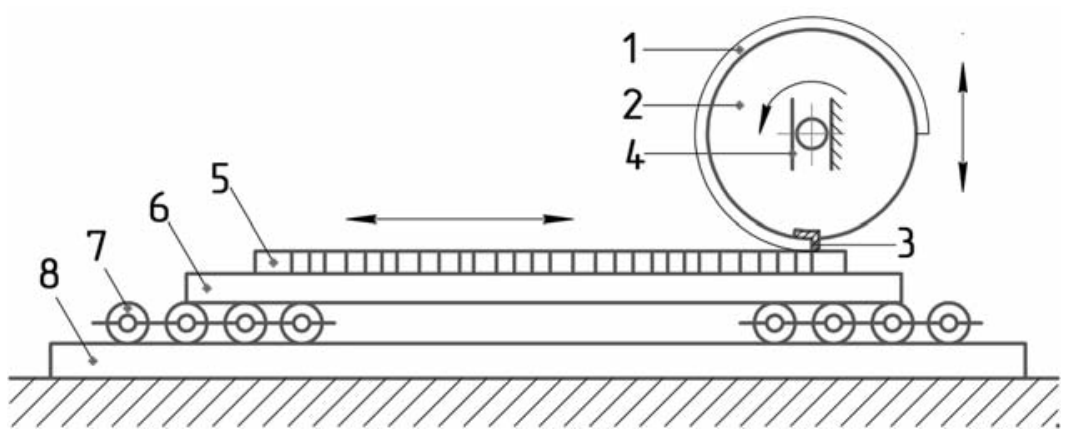

Рис. 2. Графічна схема стоп-циліндрового висікального пресу: 1 - заготовка палітурного матеріалу; 2 - металевий циліндр; 3 - затискачі; 4 - куліса; 5 - висікальна форма; 6 - талер; 7 - рольганг; 8 - нерухома станина 
Кривошипи мають радіуси $\mathrm{R}_{2}$ (рис. 3), що пропорційно пов'язані 3 довжиною висікальної форми L співвідношенням $\mathrm{R}_{2}=$ $=\mathrm{L} / 2 \pi$, виходячи $з$ умови необхідності подачі протягом одного оберту кривошипів стрічки палітурного матеріалу довжиною $L=2 \pi R_{2}$ і узгодження лінійної швидкості висікальної форми та стрічки в момент висікання розгорток.

Для зрівноваження динамічних навантажень, що виникають при обертанні плит, кривошипи мають встановлені на своїх протилежних, від місць кріплення плит, кінцях ланок противаги.

Пристрій складається із формної 1 і гладкої 2 плит, які шарнірно закріплені на кривошипах 3-6, при цьому кривошипи 3, 4 розміщені дзеркально відносно кривошипів 5, 6; штанцювальної форми 7, зубчастих коліс 8, 9, противаг 10-13, встановлених на кінцях кривошипів 3-6, стрічко-ведучого механізму з валиками 14-17, стрічки палітурного матеріалу 18 , яка розмотується із рулону 19 , ножа 20 і контр-ножа 21 для розрізування стрічки палітурного матеріалу, з висіченими розгортками, на окремі аркуші, а також палети 22 із аркушами матеріалу 23, в яких знаходяться висічені розгортки обкладинок.

Технологічний процес висікання розгорток обкладинок здійснюється у такій послідовності: за допомогою зубчастих коліс 8, 9 синхронно приводяться у рух верхня 1, з висікальною формою, і нижня 2 плоскі плити; верхні кривошипи 5, 6 і нижні кривошипи 3, 4 дзеркально обертаються за напрямком руху стрічки палітурного матеріалу.

Стрічка палітурного матеріалу 18 неперервно, без зупинок, подається ввідними валиками 14, 15 у зону висікання, де, в момент зближення плит 1, 2, і стрічки матеріалу напрямок і величини їх лінійної швидкості співпадають та дорівнюють швидкості руху стрічки палітурного матеріалу 18.

Висікання розгортки обкладинки із палітурного матеріалу

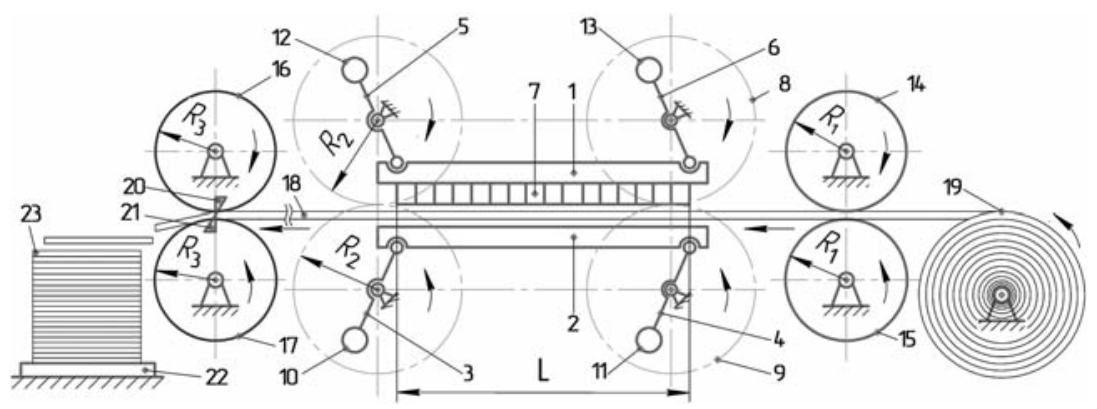

Рис. 3. Графічна схема рулонного висікального пресу із кривошипними механізмами: 1 - формна плита; 2 - допоміжна плита; 3-6 - кривошипи; 7 - штанцювальна форма; 8, 9 - зубчасті колеса; 10-13 - противаги; 14-17 - валики; 18 - стрічка палітурного матеріалу; 19 - рулон палітурного матеріалу; 20 - ніж; 21 - контрніж; 22 - палети; 
починається у момент положення кривошипів під кутом $\alpha$ до вертикальної лінії, що з'єднує осі кривошипів 3-6 (рис. 4) і закінчується у момент максимального зближення плит 1, 2 (кривошипи в цьому положенні напрямлені вздовж вертикальної лінії). Поворот кривошипів на наступний кут $\alpha$ супроводжується виходом робочих ділянок ножів із палітурного матеріалу.

Величина кута $\alpha$ визначається товщиною палітурного матеріалу і за розрахунками, складає для найбільш поширених матеріалів, наприклад, щільних картонів, менше 1,5 \% від повного обертання кривошипів.

До переліку основних пристроїв для висікання розгорток різноманітних обкладинок належать не тільки пристрої, що мають одну плоску висікальну форму, за допомогою якої здійснюється виготовлення одної розгортки обкладинки, або багатопозиційну плоску висікальну форму, за допомогою якої виготовлюється серія обкладинок кількісно обумовлена форматом видання і форматом аркуша, на якому контури розгортки будуть розміщені.

Окрему групу пристроїв для виготовлення розгорток обкладинок складають пристрої, що використовують для висікання однопозиційні висікальні форми, розташовані на багатогранній призмі, що обертається.

У пристрої для виготовлення розгорток обкладинок [9], зображеному на рис. 5, міститься вузол висікання у вигляді матриці та пуансона, де матрицею $є$ шестигранна призма із закріпленими на гранях плоскими однопозиційними висікальними формами, а пуансоном є циліндр з еластичними рукавом, який кінематично з'єднаний з кулачковим механізмом для забезпечення

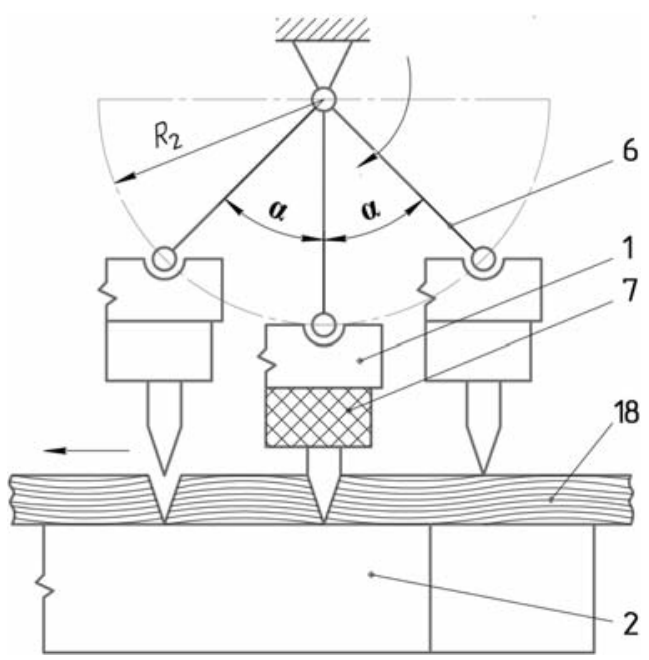

Рис. 4. Графічна схема послідовності операцій висікання розгортки обкладинки за один цикл кривошипного механізму: 1 - формна плита;

2 - допоміжна плита; 6 - кривошип; 7 - висікальна форма; 18 - стрічка палітурного матеріалу 
постійного технологічного тиску, необхідного у зоні висікання розгорток з рухомої стрічки палітурного матеріалу.

Основними перевагами пристрою є його компактність, простота конструкції, що забезпечує необхідні технічні умови для висікання розгорток необхідної якості.

На рис. 5 зображено графічну схему, удосконаленого авторами пристрою, для висікання розгорток книжково-журнальних обкладинок, який складається з шестигранної призми 1 , що обертається навколо осі $\mathrm{O}_{1}$, на гранях якої закріплено ретельно припасовані одна біля одної на ділянках, що межують з ребрами призми, плоскі висікальні форми 2, притискного циліндра 3, який обертається навколо осі $\mathrm{O}_{2}$ із еластичним рукавом 4, кулачкового механізму для забезпечення постійного і необхідного тиску для висікання розгорток з рухомої стрічки 6 палітурного матеріалу, що розмотується з рулону 5 , встановленого на осі $\mathrm{O}_{3}$, за умови заняття положення призми 1 на кожний 3 кутів $\varphi$. Механізм складається 3 важеля 7, куліси 8 з роликами 9, що контактують з профілем кулачка 10 , який встановлено на осі $\mathrm{O}_{1}$.

Габаритні розміри висікальних форм, що кріпляться на плоских гранях шестигранної призми, повинні бути технологічно тотожними для забезпечення точності висікання контурів розгорток обкладинок із задрукованих, або у інший спосіб оздоблених поверхонь палітурного матеріалу, що підлягає висіканню.

Пристрій працює у наступній технологічній послідовності. Стрічка палітурного матеріалу 6 подається з рулону у зону висікання розгорток між плоскою висікальною формою 2 та еластичним рукавом 4 циліндра 3. Обкочування циліндром плоскої

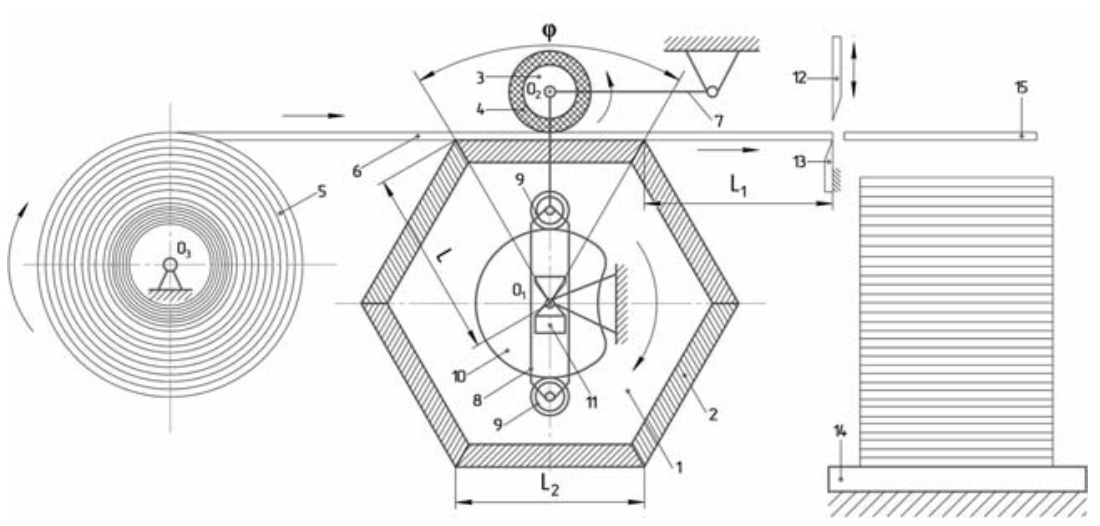

Рис. 5. Графічна схема рулонного висікального пристрою з механізмом обертової призми: 1 - обертова призма; 2 - висікальні форми на кожній грані призми; 3 - притискний циліндр; $4-$ еластичний рукав; $5-$ рулон палітурного матеріалу; 6 - стрічка палітурного матеріалу; 7 - важіль;

8 - куліса; 9 - обкочувальні ролики; 10 - кулачок; 11 - повзун;

12 - різальний ніж; 13 - протиніж; 14 - палета; 15 - аркуші палітурного матеріалу із висіченими розгортками 
висікальної форми відбувається на кут ф повороту призми 1. Зміна цього кута впливає на зміну відстані L від осі обертання призми 1 до контакту поверхонь плоскої висікальної форми 2 і еластичного рукава 4 циліндра 3, яка для забезпечення постійного і необхідного тиску у зоні висікання розгорток регулюється зміною положення куліси 8 відносно повзуна 11 завдяки обкочування роликами 9 кулачка 10.

Завершення циклу висікання розгортки обкладинки здійснюється після розрізування стрічки палітурного матеріалу на аркуші, в площині яких знаходяться розгортки, різальним ножем 12 , що виконує розрізання стрічки за допомогою протиножа 13. Відрізані аркуші 15 складуються на палету 14.

Незмінною умовою виробничої експлуатації пристрою з технологічною точністю $є$ дотримання співвідношення довжини відрізаного аркуша з висіченою розгорткою $\mathrm{L}_{1}$ і довжини висікальних форм $L_{2}$, закріплених на гранях шестигранної призми $\left(\mathrm{L}_{1}=\mathrm{L}_{2}\right)$.

У розглянутих конструкціях пристроїв для висікання розгорток інтегральних обкладинок, обкладинок з клапанами різних просторових конструкцій, півжорстких обкладинок, заготовок покривного матеріалу палітурок використовуються плоскі висікальні форми, що мають незмінні розміри і забезпечують виготовлення тотожних виробів не тільки для подальшого використання у брошурувально-палітурних технологічних процесах, при виготовленні книжково-журнальної продукції, а і забезпечують можливості виготовлення розгорток для тари та паковань.
Відомі конструкції висікальних штампів (штанц-форм) для висікання заготовок із паперу та картону книжкових обкладинок і палітурок одного формату з одною, постійною для цього формату, шириною корінця книги L (рис. 6).

Основою такого висікального штампу є цілісний лист 1 каліброваного матеріалу, що забезпечує стабільність розмірів, товщиною 15 або 18 мм, (каліброваної без сучків ударостійкої фанери з лущеного березового, букового, кленового або вільхового шпону, з'єднаного клеями на основі формальдегідних, або карбонатних смол, багатошарової склотканини з наповнювачем із поліестеру - дурамар (duramar), полімерних матеріалів пертінакс (pertinax), пермаплекс (permaplex), акрилове скло (acryglas) та ін.) у кожному із яких, за контуром майбутньої розгортки, механічними, або лазерними пристроями утворені наскрізні пазові отвори в які, згідно контуру розгортки, вставлено металеві лінійки 2 - висікальні 3, висотою 23,8 мм та бігувальні 4, висотою 23,1-23,6 мм.

Недоліком висікальних штампів такої конструкції для висікання розгорток книжкових обкладинок і палітурок, $є$ те, що висікати можливо лише розгортки із паперу та картону з незмінними розмірами.

Але, для одного книжкового формату, у різних книгах, може змінюватися кількість зошитів у книжковому блоці, що призводить до зміни ширини корінця книги. При виготовленні обкладинок або палітурок для книг одного формату і змінній ширині 
корінця перша і друга сторінки обкладинки, у них, залишаються незмінні розміри, а розмір корінцевої частини змінюється.

Таким чином, для висікання розгорток кожної нової обкладинки, або палітурки книги, у якої перша і друга сторінки мають незмінні розміри, а розмір корінцевої частини змінюється необхідно виготовлювати також і нові висікальні штампи із цілісного каліброваного листа матеріалу для кожної нової розгортки з іншою шириною корінця.

Для малотиражної та середньо тиражної книжкової продукції однакового формату і змінній ширині корінцевої частини застосування нових висікальних штампів для кожної зміни розмірів корінцевої частини $є$ значною економічно затратною складовою собівартості виготовлення книг, що впливає на конкурентоздатність такого технологічного процесу.
Для розширення технологічних можливостей і кількісного скорочення висікальних штампів для виготовлення розгорток обкладинок однакового формату і різної ширини корінцевої частини необхідно створити нову конструкції пристрою для забезпечення висікання розгорток із паперу та картону для книжкових обкладинок і палітурок, за допомогою якої можливо висікати розгортки одного книжкового формату зі змінною шириною корінця книги.

Авторами запропоновано пристрій [10], що містить основу із каліброваного листа товщиною 15 або 18 мм, у якому, механічними, або лазерними пристроями утворені наскрізні пазові отвори, в які вставлено висікальні, висотою 23,8 мм, бігувальні висотою, 23,1-23,6 мм, металеві лінійки, який додатково містить раму з направляючими, основа виконана з двох частин, наскрізні

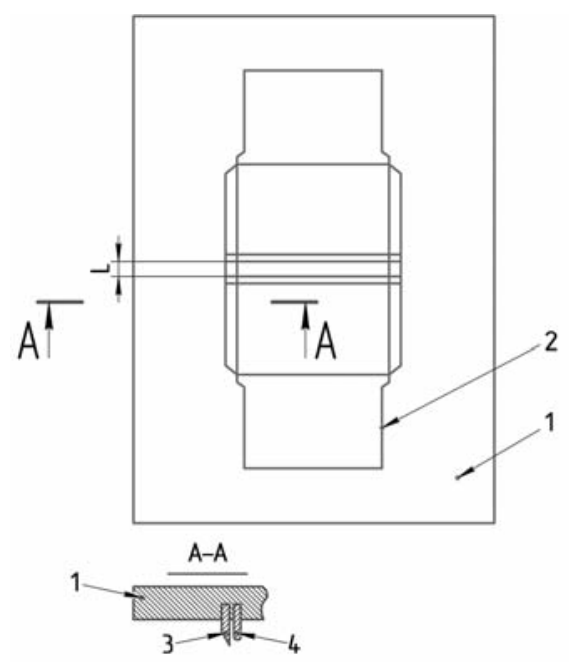

Рис. 6. Штамп для висікання заготовок із постійною шириною корінця: 1 - матеріал (основа штампа; 2 - металеві лінійки; 3 - висікальні лінійки; 4 - бігувальні лінійки; L - ширина корінця книги 
пази утворені у кожній частині основи за контуром половини майбутньої розгортки, при цьому одна частина основи закріплена нерухомо за допомогою чотирьох фіксаторів у направляючих загальної для двох частин основи рами, а друга частина основи виконана з можливістю переміщення у направляючих загальної рами на ширину $L_{3 м}$, що залежить від товщини корінця книги, за допомогою гвинтового пристрою, розміщеного на рамі.

У даному технічному вирішенні конструктивні особливості пристрою, для висікання розгорток із паперу та картону книжкових обкладинок і палітурок одного формату зі змінною шириною корінця, не потребують виготовлення нових цілісних штампів, а дозволяють зробити швидке переналагодження для висікання розгорток, у яких змінена ширина корінця від попереднього типу обкладинок до наступного.

Для реалізації цієї можливості пристрій додатково містить раму з направляючими, основа виконана з двох частин, де одна частина основи закріплена нерухомо за допомогою чотирьох фіксаторів у направляючих загальної для двох частин основи рами, а друга частина основи виконана з можливістю переміщення у направляючих загальної рами на ширину, що залежить від товщини корінця книги, за допомогою гвинтового пристрою, розміщеного на рамі.

Порівняльний аналіз технічного вирішення, що пропонується, дозволяє зробити висновок, що запропоноване авторами технічне вирішення має суттєві ознаки, які відрізняють його від відомих технічних рішень і обумовлює досягнення поставленого завдання за рахунок створення можливості переміщення другої частини основи у рамі на ширину, що залежить від товщини корінця книги за допомогою гвинтового пристрою, розміщеного на направляючих рами.

Суть і принцип дії запропонованого технічного вирішення пояснюються кресленнями (рис. 7), де подана конструктивна схема пристрою.

У склад пристрою входить: рама з направляючими 1, перша частина основи 2, друга частина основи 3, наскрізні пазові отвори 4 за контуром половини розгортки обкладинки у першій та другій частині основи, висікальні металеві лінійки 5 в першій і другій частині основи, бігувальні металеві лінійки 6 у першій і другій частині основи, фіксатори 7 першої частини основи, гвинтовий пристрій переміщення 8 другої частини основи, регульована відстань між основами, що залежить від розмірів корінця книги $L_{3 м}$.

Пристрій застосовується, як висікальний інструмент у висікальних пресах плоско-паралельної дії площини інструменту до площини паперу, або картону, із яких передбачається висікання розгорток обкладинок.

Налаштування пристрою відбувається наступним чином: попередньо у двох частинах основи, за контуром майбутньої розгортки обкладинки, механічними, або лазерними пристроями утворені наскрізні пазові отвори, в які вставлені висікаль- 
ні, висотою 23,8 мм і бігувальні висотою, 23,1-23,6 мм металеві лінійки; перша частина основи закріплена нерухомо чотирма фіксаторами у направляючих загальної для двох частин основи рами, а друга частина основи приєднана до гвинтового пристрою, розміщеного на рамі, за рахунок якого здійснене переміщення другої частини основи у направляючих рами на ширину, що відповідає ширині корінця книги, для якої висікається розгортка обкладинки.

Після налаштування пристрою для висікання тиражу розгортки книжкової обкладинки, пристрій закріпляється на верхній плоскій плиті висікального пресу, яка, разом з пристроєм, під час технологічного циклу, переміщається у нижнє фіксоване

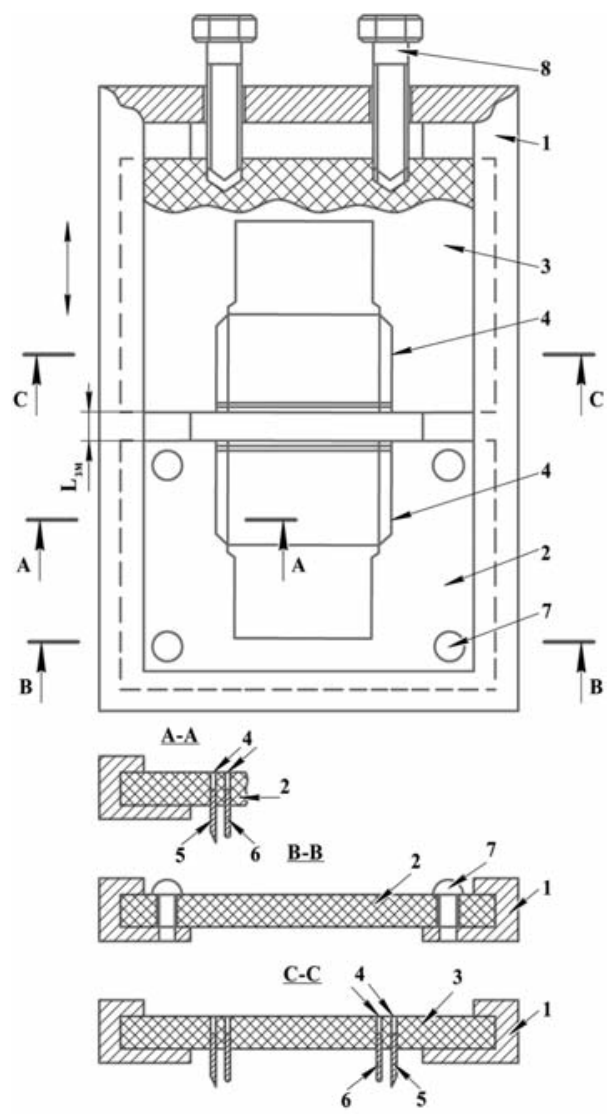

Рис. 7. Пристрій для висікання розгорток обкладинок одного формату і змінній ширині корінця: 1 - рама з направляючими; 2 - перша частина основи штампа; 3 - друга частина основи штампа; 4 - наскрізні пазові отвори; 5 - висікальні металеві лінійки; 6 - бігувальні металеві лінійки; 7 - фіксатори; 8 - гвинтовий пристрій переміщення; $\mathrm{L}_{3 м}-$ регульована відстань 
положення, в якому відбувається висікання розгортки обкладинки із паперу, або картону.

Під час холостого ходу плити із пристроєм у початкове технологічне положення, відбувається заміна висіченої розгортки обкладинки на наступний аркуш паперу або картону. Цикл висікання повторюється на кількість тиражу розгорток обкладинки.

Після завершення висікання одного тиражу розгорток обкладинки, пристрій знімається. За допомогою гвинтового пристрою друга частина основи переміщається на розмір, що відповідає ширині корінця нової обкладинки, пристрій закріпляється на верхню плиту висікального пресу і технологічний процес висікання нової розгортки обкладинки відбувається у такий же спосіб.

Представлений пристрій дозволяє здійснювати висікання розгорток із паперу та картону книжкових обкладинок і палітурок одного формату зі змінною шириною корінця, на відміну від штампів, виготовлення яких буде здійснюватися для висікання розгорток кожної нової обкладинки, при зміні ширини корінця.

\section{Висновки}

Дослідження конструктивних особливостей побудови пристроїв і штампів для виготовлення розгорток півжорстких Книжково- журнальних обкладинок дозволяє систематизувати використання висікально-пресувального обладнання, здатного забезпечити економічно доцільне виготовлення ергономічних і ресурсозберігаючих розгорток для інтегральних обкладинок, обкладинок з клапанами різних просторових конструкцій, заготовок покривного матеріалу палітурок, із матеріалів, що мають визначені характеристики міцності, пластичності і товщини, які обмежують використання будьякого іншого обладнання для висікання розгорток із картону, паперу i штучних палітурних матеріалів.

Враховуючи відмінність висікання розгорток для паковань і обкладинок для книжкової продукції, яка полягає в тому, що книжкові блоки одного формату можуть мати корінцеву частину за розмірами відмінну одне видання від іншого, через зміну кількості сторінок, а, відповідно, і товщини корінцевої частини книжкового блоку, при збереженні всіх інших розмірів розгорток сталими, проведене дослідження відмінностей сприяло створенню багатофункціональної роз'ємної висікальної форми у якої, одна частина залишається нерухомою, а інша здійснює дискретні переміщення на визначену ширину, що відповідає ширині корінця книги, для якої висікається розгортка обкладинки.

\section{Список використаної літератури}

1. Палюх О. О. Дослідження конструктивних відмінностей окремих видів півжорстких обкладинок / О. Палюх // Технологія і техніка друкарства. Київ: КП। ім. Ігоря Сікорського, 2018. Вип. 4(62). С. 48-59. DOI

2. Пат. 134723 України B42D 3/00. Напівжорстка книжково-журнальна обкладинка для криття блоків, підібраних позошитно і прошитих нитками, окантованих і обрізаних з трьох сторін / Киричок П. О., ПалюхО.О. / Заявл. 16.05.2018. 
3. COУ 22.2-02477019-15:2010 Поліграфія. Обкладинки та палітурки / Держкомтелерадіо України. Київ, 2010.

4. Маїк В. 3. Технологія брошурувально-палітурних процесів / В. 3. Маїк. Львів, 2011.488 с.

5. Производственные линии SPO 1600, 2000 для печатания и высекания упаковок из гофрированного и комбинированного картона. Проспект фирмы БОБСТ, Лозанна, № 8701.

6. Шредер В. Л. Упаковка из картона / Шредер В. Л., Пилипенко С. Ф. Киев: ИАЦ. «Упаковка», 2004. 560 с.

7. Пат. № 21874 України МКИ В31B1/16, B26F1/38. Спосіб виготовлення розгорток складної конфігурації по периметру і пристрій для його реалізації. Опубл. 30.04.98. Бюл. № 2.

8. Пат. 37279 С2 України В31В 1/16. Пристрій для виготовлення розгорток картонних упаковок / Полюдов О. М., Регей І. І., Угрін Я. М., Хведчин Ю. Й., Главацький А. С. / Заявл. 03.02.1998; Опубл. 15.05.2001. Бюл. № 4.

9. Пат. 58934 А України В31В 1/16. Пристрій для виготовлення розгорток картонних паковань / Угрін Я. М., Полюдов О. М. Регей І. І. / Заявл. 26.11.2002; Опубл. 15.08.2003. Бюл. № 8.

10. Пат. 119418 C2 України B42D 3/00. Пристрій для висікання розгорток із паперу та картону книжкових обкладинок і палітурок одного книжкового формату / Киричок П. О., Палюх О. О. / Заявл. 16.05.2018.

\section{References}

1. Paliukh, O. O. (2018). Doslidzhennia konstruktyvnukh vidminnostei okremykh vydiv pivzhorstkykh obkladynok. Journal of Tekhnolohiia i tekhnika drukarstva, 4(62), 48-59. DOI [in Ukrainian].

2. Kyrychok, P. O. \& Paliukh, O. O. Napivzhorstka knyzhkovo-zhurnalna obkladynka dlia kryttia blokiv, pidibranykh pozoshytno i proshytykh nytkamy, okantovanykh i obrizanykh z triokh storin // Patent 134723. Ukraine. B42D 3/00. Publish 16.05.2018 [in Ukrainian].

3. (2010). Polihrafiia. Obkladynky ta paliturky: SOU 22.2-0247701915:2010. Kyiv: Derzhkomteleradio [in Ukrainian].

4. Maiik, V. Z. (2011). Tekhnolohiia broshuruvalno-paliturnykh protsesiv. Lviv, 488 p. [in Ukrainian].

5. Proizvodsvennye linii SPO 1600, 2000 dlya pechataniya $i$ vysekaniya upakovok iz gofrirovannogo i kombinirovannogo kartona. Prospekt firmy $B O B S T$, № 8701. Lozanna [in Russian].

6. Shreder, V. L. \& Pylypenko, S. F. (2004). Upakovka iz kartona. Kiev: IATs ,Upakovka', 560 p. [in Russian].

7. Sposib vyhotovlennia rozhortok skladnoi konfihuratsii po perymetru $i$ prystrii dlia ioho realizatsii // Patent 21874. Ukraine. B31B1/16, B26F1/38. Publish 30.04.98. [in Ukrainian].

8. Poliudov, O. M. \& Rehei, I. I. \& Uhrin, Ya. M. \& Khvedchyn, Yu. Yo. \& Hlavatskyi, A. S. Prystrii dlia vyhotovlennia rozhortok kartonnykh upakovok // Patent 37279 S2. Ukraine. B31B 1/16. Publish 15.05.2001 [in Ukrainian].

9. Uhrin, Ya. M. \& Poliudov, O. M. \& Rehei, I. I. Prystrii dlia vyhotovlennia rozhortok kartonnykh pakovan // Patent 58934 A. Ukraine. B31B 1/16. Publish 15.08.2003 [in Ukrainian].

10. Kyrychok, P. O. \& Paliukh, O. O. Prystrii dlia vysikannia rozhortok iz paperu ta kartonu knyzhkovykh obkladynok i paliturok odnoho knyzhkovoho formatu // Patent 119418 S2. Ukraine. B42D 3/00. Publish 16.05.2018 [in Ukrainian]. 
Учитывая отличия высекания разверток упаковок и обложек для книжной продукции, которые заключаются в том, что книжные блоки одного формата могут иметь корешковую часть по размерам отличную одно издание от другого, через изменение количества страниц, а, соответственно, и толщины корешковой части книжного блока, при сохранении всех остальных размеров разверток постоянными, проведенное исследование различий способствовало созданию многофункциональной разъемной высекальной формы, в которой одна часть остается неподвижной, а другая осуществляет дискретные перемещения на определенную ширину, что соответствует ширине корешка книги, для которой высекается развертка обложки.

Ключевые слова: полужесткая обложка; кромки; клапаны; развертка; штанц-форма; высекальное устройство; матрица; пуансон.

Considering the difference between the carving of booklets and covers for book products, which consists in the fact that book blocks of one format may have a fundamental part different in size from one edition to another due to the change in the number of pages and, accordingly, the thickness of the back part of the book block, while keeping all other dimensions of the scanner constant, the study of the differences contributed to the creation of a multifunctional detachable carving shape in which one part remains stationary and the other disks Retnje move into a certain width corresponding to the width of the spine of the book for which of punching of scan covers.

Keywords: semi-rigid cover; edges; valves; sweep; die-shape; punching device; matrix; punch. 